\title{
PARTICIPANTS OF MATERIAL PROCESSES IN GRAMMATICAL METAPHORS INVOLVING THE VERBS MAKE AND TAKE
}

\author{
Dede Ismail \\ Politeknik Komputer Niaga LPKIA, Indonesia \\ Email: ismailando@yahoo.com
}

APA Citation: Ismail, D. (2020). Participants of material processes in grammatical metaphors involving the verbs make and take. Indonesian EFL Journal, 6(1), 55-62. doi: 10.25134/ieflj.v6i1.2638.

Published: 01-01-2020

\begin{abstract}
This article, based on the transitivity system in a systemic functional linguistic study, is focused on the participants of material processes in grammatical metaphors involving the verbs Make and Take. The objective of this study is to analyze how the participants play a significant role in determining the processes of grammatical metaphors in the clauses. The data were taken from the Corpus of Contemporary American English from 2015 to 2017. The qualitative method was employed since the data were in the form of words rather than numbers. The result of this research showed that the participants of material processes are actors and scopes rather than actors and goals as they commonly occur in material processes. Scopes are represented in the clause since the processes of doing are expressed only by the participants. However, in the congruent forms, the participants of material processes are actors and goals since their participants are expressed as 'things' rather than expressing the process of doing as they occur in the non-congruent forms termed as grammatical metaphors.
\end{abstract}

Keywords: grammatical metaphor; congruent; non-congruent; material processes; participant; goal; scope.

\section{INTRODUCTION}

Some expressions such as made a promise, had a dinner, or took a look can be frequently found in contemporary literature on English. In a traditional way, they are termed as "light verbs" (Jesperson, 1942, p. 117) where the meaning of the expressions are represented by the nominal groups rather than the verbs. In a systemic functional linguistics, such construction is categorized as "grammatical metaphor" (Bloor \& Bloor, 2004, p. 126). A grammatical metaphor occurs to the nominalization coupled with a verb which is semantically almost empty. The nominalized form itself is designated noncongruent. "In the driver looked at Whisper, the form looked has been chosen; however, the author might have used the non-congruent grammatical forms took a look or had a look, but not to" (Bloor \& Bloor, 2004, p. 127). Meanwhile, the term congruent occurs when the meaning of the process is normally realized by the verb rather than nominal group as in the driver looked at Whisper. They are actually variant ways of saying the same thing. In a transitivity system, Halliday and Matthiessen $(2014$, p. 241) argue that the nominal group following the verb in grammatical metaphor functions as "scope". Scope is a "participant" of "material process". Material process is one of the processes in the transitivity system. These processes are realized by the verbs, while participants are the entities involved in the process themselves (Bloor \& Bloor, 2004, p. 109). According to Gerrot and Wignell (1995, p. 61 ), the incumbent participant in material process is commonly represented by "goal" as in $\mathrm{He}$ [actor] took [material process] two cases [goal]. The participant in material process, however, is scope when the grammatical metaphor occurs as in $\mathrm{He}$ [actor] took [material process] a shower [scope] (Bloor \& Bloor, 2004, p. 114). For this reason, the writer, based on a systemic functional linguistics study, focuses the research on the following formulations: 1) How can the participants of material process be the scopes in grammatical metaphors? and 2) What participants are represented in material processes when the congruent forms?

A number of research studies on the expressions consisting of verb plus nominal groups have been conducted. The studies may vary such as translation, syntax, and semantic. One of them was accomplished by Wittenberg and Piñango (2011). They focus the research on linguistic architecture, cross-modal lexical decision, argument structure, syntactic composition, and semantic composition. They argue that in light verb constructions, such as Henry gave Elsa a kiss, Henry is represented as the kisser and Elsa is the 'kiss-ee', although the main verbal predicate is give, not kiss. In these constructions, argument linking results from joint predication between give and a kiss evoke 


\section{Dede Ismail}

Participants of material processes in grammatical metaphors involving the verbs make and take

mismatching syntactic and semantic structures. They also illustrate the comparison between a non-light sentence and a light verb construction. In a non-light sentence Henry gives Elsa a rose, Henry is the 'giver' (the Agent), Elsa is the Recipient, and a rose is the entity that undergoes transfer (the Theme). In the light verb construction Henry gives Elsa an order, the noun complement contributes additional semantic roles: Henry is the ordered, and thus the Agent of ordering, and Elsa is the person ordered to do something. However, the order, in addition to being a participant in the event representation of the sentence, is part of a complex predicate that licenses semantic roles to the other participants in the sentence.

The second research examines the complementation of light verb constructions with the deverbal noun laugh (Giparaite, 2016). The deverbal noun laugh is analyzed in combination with high frequency light verbs have, get, give, make, and do in terms of frequency and complementation patterns in twenty English varieties: New Zealand, Canadian, Singaporean, New Zealand, Pakistani, Bangladeshi, Philippine, Ghanaian, Kenyan, South African, North American, Jamaican, Tanzanian, Hong Kong, Malaysian, Nigerian, British, Australian, Irish, and American English. Each of country, in fact, uses different light verbs corresponding to the deverbal noun laugh.

The present study differs from the previous ones since it is an effort to analyze the data, which are termed as grammatical metaphor instead of being traditionally termed as light verb, based on a systemic functional linguistics.

Meanwhile, grammatical metaphor is to refer to meaning transference in the grammar (Halliday, 1985, p. 321). This implies that the meaning is transferred from somewhere to somewhere else (Garrot \& Wignell, 1995, pp. 147-148). The grammatically metaphorical nature of the written is largely the result of nominalization, turning processes into nouns. According to Thompson (2014, pp. 238-243), the key phenomenon of grammatical metaphor is nominalization - the use of a nominal form to express a process meaning. We can usually recognize nominalizations by the fact that the nominal form is derived from a verbal form.

Nominalizations are frequently found in some expressions as in take a bath, have a look, and so on (Bloor \& Bloor, 2004, p. 126). They argue that the expression involving nominalizations are indentified as the examples of grammatical metaphor. In essence, they perceive bathing as 'doing' rather than 'a thing'. According to Heyvaert (2013, p. 66), a systemic functional linguistics on nominalization is closely tied up with the concept of grammatical metaphor: nominalization is presented as a major resource for the creation of 'metaphorical' rather than 'typical' lexicogrammatical realizations of semantic categories. Nominalization allows a process, more obviously realized as a verb, to be realized as a noun and hence to become a participant in a further process. In addition, nominalizations can be found when they are coupled with a verb which semantically almost empty in this context, usually take or have. Either I dined before I came or, nominalizing, I had dinner before I came are acceptable (Bloor \& Bloor, 2004, p. 114).

In grammatical metaphors, the term noncongruent is used to refer to the nominalized verbs. This term, as previously mentioned, may occur to the nominalization coupled with a verb which is semantically almost empty as in take a bath (Bloor \& Bloor, 2004, p. 127). In the driver looked at Whisper, the form looked has been chosen; the author might have used the noncongruent grammatical forms took a look or had a look, but not to. On the contrary, it is termed as congruent when the meaning of the process is normally realized by the verb as in I bathed rather than I took a bath. The usual way of encoding such phenomena in English is to opt for 'material process' with an Actor. This choice, where the process matches our perception of bathing as 'doing' rather than 'a thing', is said to be congruent (Bloor \& Bloor, 2004, p. 127).

Material processes are processes of material doing in a transitivity system. Processes are central of transitivity (Gerot \& Wignell, 1995, p. 54). Transitivity generally refers to how the meaning represented in a clause. It means that the clause is the simultaneous realization of ideational, interpersonal and textual meanings. Transitivity is also defined as 'grammar of the clause,' as a 'structural units,' for expressing a particular range of ideational meanings (Halliday, 1985, p. 42). There are three components of what Halliday calls a 'transitivity process':

1. Process: realized by verbal groups.

2. Participants: realized by nominal groups.

3. Circumstances: realized by adverbial groups and prepositional phrases.

Most material processes could reasonably be said to involve 'doing-words' (Gerot \& Wignell, 1995, p. 55; Bloor \& Bloor, 2004, p. 110). They 
express the nation that some entity physically does something which may be done to some other entity. Physical actions in the real world and their participants are Actor: the one who does the action, Goal: the one who is affected by the action, Recipient: the one who receives something, and Beneficiary: the one for whom something is done. The examples are given as follows:

\begin{tabular}{|c|c|c|c|c|c|}
\hline \multirow[t]{3}{*}{ (1) } & $\mathrm{He}$ & \multicolumn{2}{|c|}{ kicked } & \multicolumn{2}{|c|}{ the ball } \\
\hline & Participant & & Process & \multicolumn{2}{|c|}{ Participant } \\
\hline & Actor & & rial & \multicolumn{2}{|c|}{ Goal } \\
\hline \multirow[t]{2}{*}{ (2) } & I & gave & \multicolumn{2}{|c|}{ my love } & a ring \\
\hline & Actor & Material & \multicolumn{2}{|c|}{ Recipient } & Goal \\
\hline \multirow[t]{2}{*}{ 3) } & I & made & \multicolumn{2}{|c|}{ my love } & a cake \\
\hline & Actor & Material & & ficiary & Goal \\
\hline
\end{tabular}

There are actually six different process types in a transitivity system: Material, Behavioral, Mental, Verbal, Relational, and Existential. However, to limit the research, the writer only focuses on material processes since they are mostly found in contemporary literatures on English which apply the expressions categorized as grammatical metaphors.

Instead of goal, recipient, and beneficiary in material process, there is one more participant which may be incumbent on material processes called 'scope' (Sujatna, 2013, p. 37), or it is termed as 'range' by Gerot and Wignell (1995, p. 57). Scope is unique because it is a participant derived from nominalization of the verb in the material process. The following are the examples:

\begin{tabular}{|c|l|l|}
\hline She & took & \multicolumn{1}{l}{ a bath } \\
\hline Actor & Material & Scope/Range \\
\hline She & made & a leap \\
\hline Actor & Material & Scope/Range \\
\hline
\end{tabular}

The examples above describe took a bath and made a leap, whereas $a$ bath and a leap are nominalizations of the verb, can be changed into she bathed and she leapt. Both of the nominalizations, $a$ bath and a leap, are called 'scope'. The scope of a material clause is not in any way affected by the performance of the process. This pattern has given a rise to a form expression that is very common in Modern English, exemplified by have a bath, do some work, make a mistake, take a rest. Here, the verb is lexically general; the process of the clause is expressed only by the noun functioning as scope or range (Halliday \& Matthiessen, 2014).

English (together with some together with some other languages) has tendency to nominalize certain events which might be seen as essentially process and which often have a nonnominal synonym. Sometimes these nominalizations are coupled with a verb which has little lexical meaning, a verb which semantically almost empty in this context, usually take or have. Such verbs are sometimes said to be delexicalized because they lost their full lexical content and become almost 'dummies'. Thus, as previously mentioned, we can say I dined before I came or, nominalizing, I had dinner before I came, and in informal conversation we would usually prefer the second expression (Bloor \& Bloor, 2004, p. 114). The term used in systemic functional linguistics for items like $a$ bath in $I$ took a bath is range or scope.

The last component in material processes, which is realized by adverbial groups and prepositional phrases, is called 'circumstance'. According to Gerot and Wignell (1995, p. 52), circumstances answer the question as when, where, why, how, how many and as what. Bloor and Bloor (2004, p. 132) argue that circumstances fall into nine types: Extent, Location, Manner, Cause, Contingency, Accompaniment, Role, Matter and Angle. Meanwhile, Gerot and Wignell (1995, p. 52) assert that circumstances realize meanings about: Time, Place, Manner, Cause, Accompaniment, Matter, and Role.

\section{METHOD}

The method applied to study the data is qualitative since the data collected is descriptive, concerned with the process rather than with products, used logical analysis, and it is in the form of words rather than a number (Bogdan \& Biklen, 1992, p. 29). Due to that, several steps are taken to conduct this research: data collection techniques and data analysis techniques.

The data collecting in this research applies two techniques. First, the writer listed some text containing the grammatical metaphors which involve the verbs Make and Take in the Corpus of Contemporary American English from 2015 to 2017. Finally, the grammatical metaphors involving these two verbs are sorted. They have to be transitive verbs both in the non-congruent and in the congruent form. Consequently, the difference between the two forms can be described in a transitivity system.

After collecting and sorting the data, the writer (1) analyzed, based on a systemic functional linguistic study, the participants of material processes in the grammatical metaphors which involve the verbs Make and Take, and (2) 


\section{Dede Ismail}

Participants of material processes in grammatical metaphors involving the verbs make and take

analyzed what participants which may be represented when the congruent forms occur.

\section{RESULTS AND DISCUSSION}

Based on systemic functional linguistics study, this section describes (1) how the participants of material processes in grammatical metaphors, which involve the verb Make and Take, may be the scopes in the grammatical metaphors, termed as 'non-congruent forms', and (2) what participants are represented in the congruent

forms. As previously mentioned, the findings are taken from the Corpus of Contemporary American English from 2015 to 2017. A tenfinding discussion is divided into two parts: Verbs Make Involved and Verbs Take involved.

\section{Verbs Make involved}

\section{Data 1:}

"My birds make a mess of their water in no time" (MAG: Mother Earth News, Apr/May2015 Issue 269, p. 89-91. 3p).

\begin{tabular}{|l|l|l|l|}
\hline My birds & \multicolumn{1}{l}{ make } & a mess of their water & in no time. \\
\hline Actor & Material & Scope & Circumstance \\
\hline
\end{tabular}

In a systemic functional linguistics, the nominal group a mess of their water involving the verb make is grammatical metaphor. It occurs since the nominal group represents the process of doing rather than a thing. Meanwhile, the verb make is semantically empty. The verb make is categorized as material process because a mess, as the head of the nominal group, is basically a nominalization of the verb mess which is, in transitivity system, categorized as material process. Due to the nominalization, the participant in the material process is scope rather than goal as it commonly occurs in transitivity system.

Since mess is a nominalization of the verb in material process, My birds make a mess of their water in no time can be changed into My birds mess their water in no time. It can be argued that a new participant is represented when the congruent form occurs. In the non-congruent form, the participants of material process are actor and scope; however, the participants represented in the congruent form are actor and goal. The illustration is given as follows:

\begin{tabular}{ll|l|l|l|} 
Non-congruent: & My birds & make & \multicolumn{2}{l}{ a mess of their water in no time. } \\
\cline { 2 - 5 } & Actor & Material & Scope & Circumstance \\
Congruent: & My birds & mess & their water & in no time. \\
& Actor & Material & Goal & Circumstance \\
\hline
\end{tabular}

Data 2:

"9 students made a gain of more than one level" (NEWS: Washington Post, 5 February 2015).

\begin{tabular}{|l|l|l|}
\hline \multicolumn{1}{l}{9 students } & \multicolumn{1}{l}{ Made } & a gain of more than one level. \\
\hline Actor & Material & Scope \\
\hline
\end{tabular}

The above data also shows that the nominal group a gain of more than one level involving the verb make is grammatical metaphor since the nominal group represents the process of doing rather than a thing. The verb make is also semantically empty in this context and categorized as material process since gain is a nominalization of the verb gain which is categorized as material process. The nominal group is also categorized as scope because of

Non-congruent:

Congruent: nominalization and the process of doing is expressed by only the nominal group.

Since gain is a nominalization of the verb in material process, 9 students made a gain of more than one level can be changed into 9 students gained more than one level. Here, the noncongruent form represents actor and scope; however, the congruent form represents actor and goal as the new participant. A new participant is represented in the congruent form as given in the following illustration:

\begin{tabular}{lll|l|} 
Non-congruent: & \multicolumn{1}{l}{9 students } & made & \multicolumn{1}{l}{ a gain of more than one level. } \\
\cline { 2 - 4 } & Actor & Material & Scope \\
\hline \multirow{3}{*}{ Congruent: } & 9 students & gained & more than one level. \\
\hline & Actor & Material & Goal \\
\hline
\end{tabular}


Data 3:

"One could make an argument of gender nonconformity" (MAG: Salon, 17 April 2017).

\begin{tabular}{|l|l|l|}
\hline One & \multicolumn{1}{l}{ could make } & an argument of gender nonconformity. \\
\hline Actor & Material & Scope \\
\hline
\end{tabular}

The nominal group an argument of gender nonconformity involving the verb make is grammatical metaphor since the nominal group represents the process of doing rather than a thing. The verb make is semantically empty and categorized as material process in the transitivity system since the head of nominal group argument is a nominalization of the verb argue. The nominal group functions as scope due to the nominalization and it expresses the process of doing in the clause.
Since argument is a nominalization of the verb in material process, one could make an argument of gender nonconformity can be changed into one could argue gender nonconformity. A new participant of material process is represented when the congruent form occurs. The non-congruent form represents actor and scope; nevertheless, the congruent form represents actor and goal as the new participant. Consider in the following illustration:

\begin{tabular}{ll|l|l|} 
Non-congruent: & \multicolumn{1}{l}{ One } & could make & an argument of gender nonconformity. \\
\cline { 2 - 4 } & Actor & Material & Scope \\
\hline \multirow{3}{*}{ Congruent: } & One & could argue & gender nonconformity. \\
& Actor & Material & Goal \\
\hline
\end{tabular}

Data 4:

"The administration will make an assertion of executive privilege" (ACAD: Brigham Young University Law Review, Provo Vol. 2017, Iss. 2, (2017): 225-329).

The administration will make an assertion of executive privilege.

\begin{tabular}{|l|l|l|}
\hline Actor & Material & Scope \\
\hline
\end{tabular}

The nominal group an assertion of executive privilege involving the verb make is grammatical metaphor since the nominal group represents the process of doing rather than a thing. The verb make is semantically empty and categorized as material process in the transitivity system since an assertion is a nominalization of the verb assert. The nominal group functions as scope due to the nominalization or because it expresses the process of doing in the clause.
Since assertion is a nominalization of the verb in material process, The administration will make an assertion of executive privilege can be changed into The administration will assert executive privilege. The non-congruent form represents actor and scope; nevertheless, the incumbent participants in the congruent form are actor and goal. A new participant of material process is represented when the congruent form occurs as follows:

Non-congruent: $\quad$ The administration will make an assertion of executive privilege.

Congruent: $\quad$ The administration will assert executive privilege.

\begin{tabular}{|l|l|l|}
\hline Actor & Material & Scope \\
\hline \multicolumn{1}{|l|}{ The administration } & \multicolumn{1}{l|}{ will assert } & \multicolumn{1}{l|}{ executive privilege. } \\
\hline Actor & Material & Goal \\
\hline
\end{tabular}

Data 5:

"The island made a payment on the interest of about \$628,000" (NEWS: New York Times, Section B; Column 0; Business/Financial Desk; Pg. 1, 2015).

\begin{tabular}{|l|l|l|}
\hline The island & \multicolumn{1}{l}{ made } & a payment on the interest of about $\$ 628,000$. \\
\hline Actor & Material & Scope \\
\hline
\end{tabular}

The nominal group a payment on the interest of about $\$ 628,000$ involving the verb made is grammatical metaphor because the nominal group represents the process of doing rather than a thing. In a transitivity system, the verb made is a material process because a payment is a 


\section{Dede Ismail}

Participants of material processes in grammatical metaphors involving the verbs make and take

nominalization of the verb pay which is categorized as material process. The participant of this material process is the nominal group $a$ payment on the interest of about $\$ 628,000$ which is categorized as scope. It is scope since it expresses the process of doing in the clause.

Since payment is a nominalization of the verb in material process, The island made a payment on the interest of about $\$ 628,000$ can be changed into The island paid the interest of about $\$ 628,000$. Here, the non-congruent form represents actor and scope; nevertheless, the incumbent participants in the congruent form are actor and goal. The congruent form represents a different participant as illustrated in the following comparison:

Non-congruent: $\quad$ The island made a payment on the interest of about $\$ 628,000$.

Congruent:

\begin{tabular}{|c|c|c|}
\hline Actor & Material & Scope \\
\hline The island & paid & the interest of about $\$ 628,000$. \\
\hline Actor & Material & Goal \\
\hline
\end{tabular}

\section{Verbs Take involved}

\section{Data 6:}

"They take a ride on a roller coaster at Luna Park" (MAG: People, 9/7/2015, Vol. 84 Issue 10, p12-20. 6p. 24 Color Photographs).

\begin{tabular}{|l|l|l|l|}
\multicolumn{1}{l}{ They } & take & \multicolumn{1}{l}{ a ride on a roller coaster } & at Luna Park. \\
\hline Actor & Material & Scope & Circumstance \\
\hline
\end{tabular}

In a systemic functional linguistics, the nominal group a ride on a roller coaster involving the verb take is grammatical metaphor. It occurs since the nominal group represents the process of doing rather than a thing and the verb take is semantically almost empty. The verb take, in a transitivity system, is material process because ride, as the head of the nominal group, is basically a nominalization of the verb ride which is categorized as material process. The participant in this material process is scope since the process of the clause is expressed by only the nominal group.

\begin{tabular}{|c|c|c|c|c|c|}
\hline \multirow[t]{2}{*}{ Non-congruent: } & They & take & \multicolumn{2}{|c|}{ a ride on a roller coaster } & at Luna Park. \\
\hline & Actor & Material & Scope & & Circumstance \\
\hline \multirow[t]{2}{*}{ Congruent: } & They & ride & a roller coaster & at Lun & \\
\hline & Actor & Material & Goal & \multicolumn{2}{|c|}{ Circumstance } \\
\hline
\end{tabular}

Data 7:

"I take a sip of my Fanta" (FIC: Kenyon Review, Christle \& Michele, 2015).

\begin{tabular}{|l|l|l|}
\multicolumn{1}{l}{ take } & a sip of my Fanta. \\
\hline Actor & Material & Scope \\
\hline
\end{tabular}

In a systemic functional linguistics, the nominal group a sip of my Fanta involving the verb take is grammatical metaphor. It occurs since the nominal group represents the process of doing rather than a thing, and the verb take is semantically almost empty. The verb take, in a transitivity system, is material process because sip, as the head of the nominal group, is basically
Since ride is a nominalization of the verb in material process, They take a ride on a roller coaster at Luna Park can be changed into They ride a roller coaster at Luna Park. It can be argued that when the congruent form occurs, a new participant is represented in the clause. The non-congruent form represents actor they and scope $a$ ride on a roller coaster; nevertheless, the incumbent participants in the congruent form are actor they and goal a roller coaster. The illustration is given as follows: a nominalization of the verb sip which is categorized as material process. The participant in this material process is scope since the process of the clause is expressed by only the nominal group.

Since sip is a nominalization of the verb in material process, I take a sip of my Fanta can be changed into I sip my Fanta. When the congruent 
form occurs, a new participant is represented in the incumbent participants in the congruent form the clause. The non-congruent form represents actor $I$ and scope $a$ sip of my Fanta; nevertheless, are actor $I$ and goal my Fanta. The following illustration shows the comparison:

\begin{tabular}{ll|l|l|} 
Non-congruent: & \multicolumn{1}{l}{ take } & a sip of my Fanta. \\
& Actor & Material & Scope \\
Congruent: & $I$ & sip & my Fanta. \\
& Actor & Material & Goal \\
\hline
\end{tabular}

Data 8:

"She took an inventory of body parts" (FIC: The scottie barked at midnight, 2017).

\begin{tabular}{|l|l|l|}
\multicolumn{1}{l}{ She } & took & an inventory of body parts. \\
\hline Actor & Material & Scope \\
\hline
\end{tabular}

In a systemic functional linguistics, the nominal group an inventory of body parts involving the verb take is grammatical metaphor. It occurs since the nominal group represents the process of doing rather than a thing and the verb take is semantically almost empty. The verb take, in transitivity system, is material process because inventory, as the head of the nominal group, is basically a nominalization of the verb inventory which is categorized as material process. The participant in this material process is scope since the process of the clause is expressed by only the nominal group.

Non-congruent:

Congruent:

\begin{tabular}{|c|c|c|}
\hline She & took & an inventory of body parts. \\
\hline Actor & Material & Scope \\
\hline She & inventoried & body parts. \\
\hline Actor & Material & Goal \\
\hline
\end{tabular}

Data 9:

"Scarsella took a punch to the cheek" (NEWS: Minneapolis Star Tribune, 30 January 2017).

\begin{tabular}{|l|l|l|}
\hline Scarsella & took & \multicolumn{1}{l}{ a punch to the cheek. } \\
\hline Actor & Material & Scope \\
\hline
\end{tabular}

In a systemic functional linguistics, the nominal group a punch to the cheek involving the verb took is grammatical metaphor. It occurs since the nominal group represents the process of doing rather than a thing and the verb took is semantically almost empty. The verb took, in transitivity system, is material process because punch, as the head of the nominal group, is basically a nominalization of the verb punch which is categorized as material process. The participant in this material process is scope because of nominalization and the process of the clause is expressed by only the nominal group.

\begin{tabular}{ll|l|l|} 
Non-congruent: & \multicolumn{1}{l}{ Scarsella } & Took & a punch to the cheek. \\
\hline \multirow{3}{*}{ Congruent: } & Actor & Material & Scope \\
\hline & Scarsella & punched & the cheek. \\
\hline & Actor & Material & Goal \\
\hline
\end{tabular}




\section{Data 10:}

"I took a bite of my rhubarb pie" (NEWS: Minneapolis Star Tribune, 30 January 2017).

\begin{tabular}{|l|l|l|}
\hline I & took & a bite of my rhubarb pie. \\
\hline Actor & Material & Scope \\
\hline
\end{tabular}

In a systemic functional linguistics, the nominal group a bite of my rhubarb pie involving the verb took is grammatical metaphor. It occurs since the nominal group represents the process of doing rather than a thing and the verb took is semantically almost empty. The verb took, in a transitivity system, is material process because bite, as the head of the nominal group, is basically a nominalization of the verb bite which is categorized as material process. The participant in this material process is scope because of nominalization and the process of the clause is expressed by only the nominal group.

Since bite is a nominalization of the verb in material process, I took a bite of my rhubarb pie can be changed into I bit my rhubarb pie. It can be argued that when the congruent form occurs, a new participant is represented in the clause. Here, the non-congruent form represents actor $I$ and scope $a$ bite of my rhubarb pie; nevertheless, the incumbent participants in the congruent form are actor $I$ and goal my rhubarb pie. The following illustration shows the difference:

Non-congruent:

Congruent:

\begin{tabular}{|l|l|l|}
$I$ & Took & a bite of my rhubarb pie. \\
\hline Actor & Material & Scope \\
\hline
\end{tabular}

I Bit my rhubarb pie.

\begin{tabular}{|l|l|l|}
\hline Actor & Material & Goal \\
\hline
\end{tabular}

\section{CONCLUSION}

Based on the analysis, it can be concluded that the participants of material processes in grammatical metaphors are actors and scopes since the head of nominal groups functioning as scopes are nominalized. Thus, the nominal groups play significant role in expressing the meaning of the clause rather than being regarded as 'things'. Consequently, the verbs become lexically empty. However, when the congruent forms occur, there are no more participants functioning as scopes. This commonly occurs to material processes. The nominal groups, as the participants in the congruent forms, are goals since the meanings of the clauses are realized by the verbs, and the nominal groups are literally regarded as 'things'. In addition, the congruent forms also prove that the grammatical metaphors are in this case categorized as material processes.

\section{ACKNOWLEDGEMENT}

I feel so blessed to have friends and family supporting me to complete this research. Since this research is a part of my thesis, I also would like to express my gratitude to my late advisor, Prof. Dr. Eva Tuckyta Sari Sujatna, M.Hum., who helped me find a solution in unique ways when all I could see was self-doubt.

\section{REFERENCES}

Bloor, T., \& Bloor, M. (2004). The functional analysis of English. London: Arnold.
Bogdan, R., \& Biklen, S. (1992). Qualitative research for education: An introduction to theory and methods. Boston: Allyn and Bacon.

Gerot, L., \& Wignel, P. (1994). Making sense of functional grammar. Sydney: Educational Enterprise.

Giparaite, J. (2016). Complementation of light verb constructions in world Englishness: A corpusbased study. Žmogus ir žodis , 18(3), 19-39.

Halliday, M. (1985). An introduction to functional grammar. London: Edward Arnold.

Halliday, M., \& Matthiessen, C. (2014). An introduction to functional grammar. London: Routledge.

Heyvaert, L. (2013). Nonimalization as grammatical metaphor: On the need for a radically systemic and metafunctional approach. In M. Travenier, \& J. R. Raveli, Nominalization as Grammatical Metaphor: Views form Systemic Functional Linguistics (p. 66). John Benjamins Publishing Company.

Jesperson, O. (1942). A modern English grammar on historical principles. Copenhagen: Ejnan Munksgaard.

Sujatna, E. T. (2013). Understanding systemic funtional linguistics. Bandung: Unpad Press.

Thompson, G. (2014). Introducing functional grammar. Oxon: Routledge.

Wittenberg, E., \& Piñango, M. M. (2011). Processing light verb constructions. The Mental Lexicon, 6(3), 393-413. 